\title{
Cervical Cancer cT3b TNM Finding v8
}

National Cancer Institute

\section{Source}

National Cancer Institute. Cervical Cancer cT3b TNM Finding v8. NCI Thesaurus. Code C139701.

Cervical cancer extending to pelvic wall and/or causing hydronephrosis or nonfunctioning kidney. (from AJCC 8th Ed.) 